\title{
Deterioration of carbonate rocks used for archeological monuments in Tauric Chersonesos (Crimea)
}

\author{
Alexander V. MOSYAGIN*, Irina V. KNAUF \& Marina S. ZELENSKAYA
}

Saint Petersburg State University, Saint Petersburg, 199034, Russia

Received February 2009; accepted July 2009

Available online September 2009

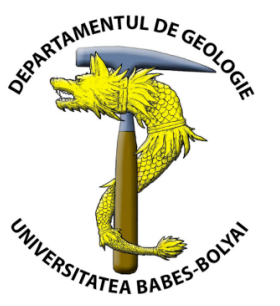

\begin{abstract}
The paper presents the mineralogy and petrography of the Proconesian marble and Chersonesian limestone used as building materials from Antiquity to the medieval times in the Tauric Chersonesos, Crimea. The deterioration process, due to the modern time's pollution and the climatic factors, is represented by forming of mainly gypsum-rich patina. The ubiquitous presence of micromycetes favors the stone decay.
\end{abstract}

Key words: marble, limestone, microfungi, gypsum-rich patina, cultural heritage, Crimea.

\section{INTRODUCTION}

Tauric Chersonesos (in the Sevastopol City) is an unique archeological preserve in Crimea, consisting of 2,500 years old monuments of ancient Greek sculpture and architecture as well as medieval constructions. The monuments are made from two carbonate rocks: the Proconesos marble and Chersonesian limestone. The Proconesos marble (Mezozoic age) was quarried near Constantinopole (Warren, 1999), while the Chersonesian limestones (the Danian stage of the early Paleogene) came from the quarries situated near the city of Chersonesos, in the region named Inkerman (Lebedinskiy, 1982). The humid sea climate and the significant air pollution by industrial gas emissions lead to intense stone deterioration, described for example by Garcia-Vallès et al. (1998). The microorganisms, inhabiting the stone surface also play a major role (Gorbushina et al., 1996; Zelenskaya and Vlasov, 2006). The composite communities of microorganisms, associated with microfungi are found on the surface of many stone monuments.

The objectives of our work are: (1) the investigation of the deterioration of carbonate rocks from Chersonesos, (2) the comparison with other cities showing industrial pollution combined with a sea climate but different in the annual average temperature e.g. Saint Petersburg and (3) a biological study of microorganisms, inhabiting the surface of these rocks.

\section{MATERIALS AND METHODS}

During the field season 2007 the marble and limestone monuments of the Tauric Chersonesos site, i.e. the "Italian Garden", the columns of the basilica (Fig. 1a), and the city wall (Fig. 1b) were studied, described and accordingly *Correspondence: A.V. Mosyagin (al.mosyagin@gmail.com) sampled. Specimens were also collected from the damaged carbonate rocks as well as patina (black crusts) on the rock's surface (Table 1). All 7 samples were studied by optical microscopy with a LOMO Min 5 microscope. For the mineral phases identification, few grams from each sample were milled in an agate mortar and measured by X-Ray powder diffraction (XRD), at room temperature, with a Dron-2 diffractometer operating at $35 \mathrm{kV}$ and $20 \mathrm{~mA}$, at a scan speed of $2^{\circ} \theta / \mathrm{min}$, from 3 to $75^{\circ} 2 \theta$, using $\mathrm{CuK \alpha} \alpha_{1}$ radiation with $\lambda=1.54051 \AA$.
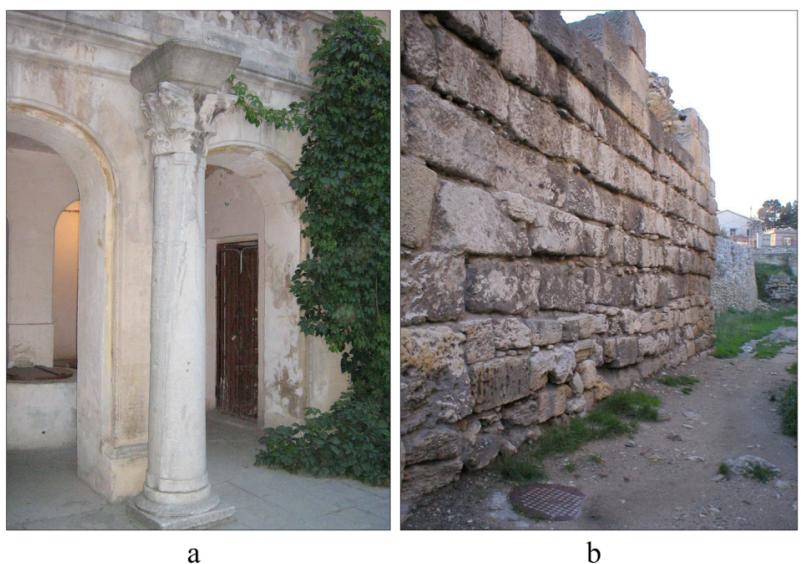

Fig. 1. Stone ancient monuments of Tauric Chersonesos: a-Proconesian marble column in the "Italian Garden"; $b$-Chersonesian limestone blocks in the city wall.

Scanning Electron Microscopy for morphological features of the minerals and biological components of the patina was performed on Au-coated samples, at $25 \mathrm{kV}$, with a ABT-55 (Akashi) microscope at Institute of Precambrian Geology and Geochronology of Russian Academy of Sciences (RAS), St. Petersburg. 
The samples for mycological analyses were collected from the same stone objects as for mineralogical analyses. A variety of biological techniques were applied to isolate fungi. In the laboratory, the fine grained samples (stone plus fungi) were spread on the surface of different media (e.g., $\mathrm{CzD}$ medium, potato-dextrose medium, oat extract medium) in Petri dishes. The microcolonial fungi were isolated from the stone samples by picking with sterile needles (at stereomicroscope). The black colonies were transferred to media in Petri dishes. The slide cultures were prepared according to De Hoog and Guarro (1995). The microscopic fungi were identified using the diagnostic keys (Ellis, 1971, 1976; von Arx, 1975; De Hoog and Guarro, 1995).

\section{RESULTS AND DISCUSSION}

The study's results have shown that the Proconesian marble collected from the surface of columns in the "Italian Garden" (samples 1-3, Fig. 2) is a heterogranular, rarely slightly dolomitized (according to the Table 1; sample 2) carbonate rock with some admixture of quartz (Table 1). The calcite grains are generally xenomorphous, with the average size of $0.2-0.3 \mathrm{~mm}$. The marble has a parallel texture macroscopically, when examined by microscope it appears massive. A parallel striation is seen on some grains.

The Chersonesian limestone (samples 4-7; Fig. 3) is an heterogranular, porous rock, which contains numerous rounded parts of microorganisms exoskeletons with an average size of 0.2-1.5 mm. Small calcite crystals (0.01-0.05 $\mathrm{mm}$ ) newly grown at the edges of exoskeletons can be seen in microphotos. The limestone consists mainly of calcite with small amounts of quartz.

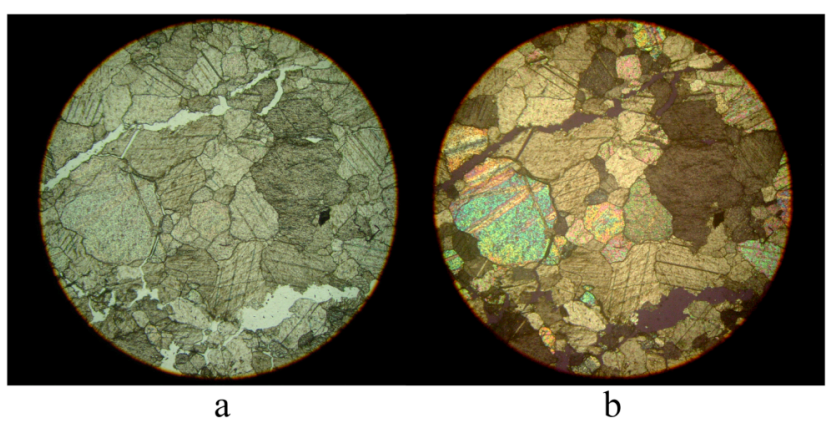

Fig. 2. Microphoto in polarized light of the Proconesian marble (thin section): $a-1 N, b-N+$.

The diameter of the microscope field is $1.2 \mathrm{~mm}$.

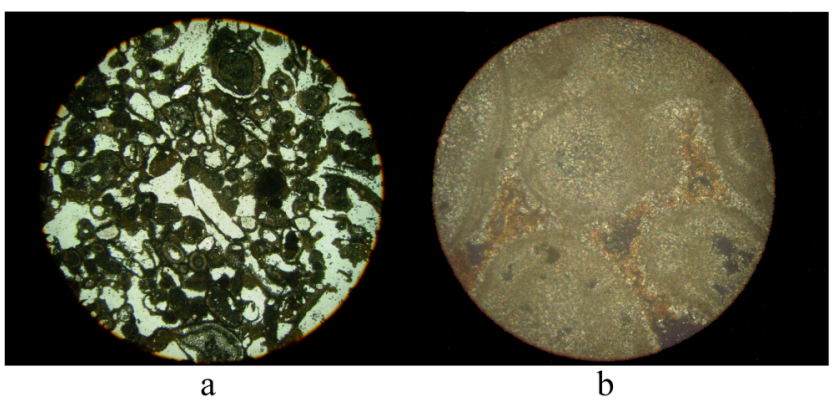

Fig. 3. Microphoto in polarized light of the Chersonesian limestone (thin section): $a-1 N, b-N+$.

The diameter of the microscope field is $1.2 \mathrm{~mm}$.

On both marble and limestone surfaces, patinas, i.e, fragile dark-grey or black crusts, are present. Two types of patinas were identified: a primary, usually massive crust covering a solid rock surface (samples 1, 5, and 6) and a secondary one (sample 7) - thinner, situated on those parts of the monuments which were already eroded by peeling of the primary crust accompanied by fragments of the rock (Fig. 4). Mineralogically, the patinas consist mainly of calcite, gypsum and, subordinate, of quartz. Gypsum can be found in the all patina developed on marble and limestone surfaces (Table 1). Other minerals which were identified as components in the patina are halite and syngenite. Halite $(\mathrm{NaCl})$ was found in the primary crusts with efflorescence, occurring on limestones (sample 6). A more rare mineral, syngenite $\mathrm{K}_{2} \mathrm{Ca}\left(\mathrm{SO}_{4}\right)_{2} \cdot \mathrm{H}_{2} \mathrm{O}$, occurs in the gypsum-rich patina on limestone (Sample 7) and his presence is most likely due to the influence of salted, sea water.

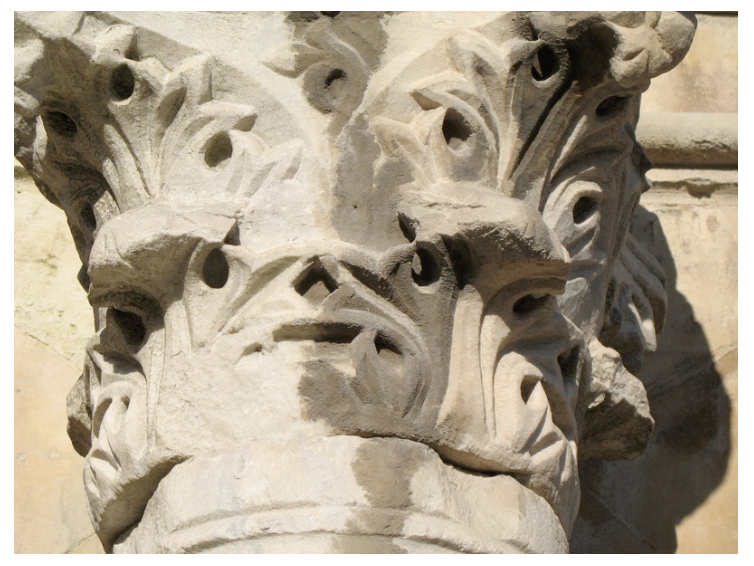

Fig. 4. Black, gypsum-rich patina on Proconesian marble.

A large number of micro-organisms species was observed in the gypsum-rich patina, as displayed in table 1 and shown in Fig. 5. The microscopic fungi (micromycetes) are represented by the genera Alternaria, Cladosporium, Penicillium etc. Microfungi isolated from the gypsum-rich crusts are common in Chersonesos and could be also found on other marble and limestone monuments (Zelenskaya and Vlasov, 2006).
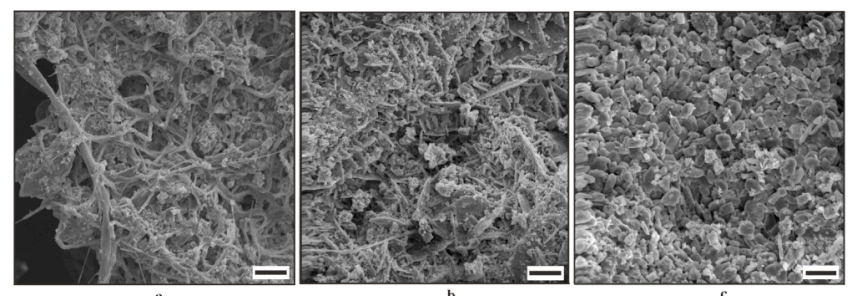

Fig. 5. SEM images of the three stages of gypsum-rich patina formation on the Chersonesian limestone: $a$-first stage: gypsum crystals beneath a compact layer of fungi hyphae (scale bar $=42$ $\mu \mathrm{m}) ; b$ - intermediate stage: microorganisms occurring among gypsum crystals (scale bar $=42 \mu \mathrm{m}) ; c$-third stage: formation of

a continuous layer of gypsum crystals (scale bar $=28 \mu \mathrm{m}$ ).

Based on the comparison of the gypsum crystals and microorganisms association, the similar stages of patina generation as those noticed by Timasheva et al. (2007) on some marble and limestone monuments of the Museum Necropolises in St. Petersburg, were also found on the surface of the Chersonesian limestones. At the initial stage it could be clearly observed on the SEM images that small gypsum crystals are covered by a biofilm consisting mainly of fungi hyphae (Fig. 5a). In the following stage, the microorganisms are seen between gypsum crystals (Fig. 5b), whereas at the last stage a continuous layer of tiny gypsum crystals covers the microorganisms (Fig. 5c). 
Table 1. List of samples of carbonate rocks collected in Chersonesos.

\begin{tabular}{|c|c|c|c|c|}
\hline $\begin{array}{l}\text { Sample } \\
\text { number }\end{array}$ & Description of the sampling points & $\begin{array}{c}\text { Mineral phases identified } \\
\text { by X-ray diffraction }\end{array}$ & \multicolumn{2}{|c|}{ Microfungi } \\
\hline \multicolumn{5}{|c|}{ Samples of Proconesian marble, collected from the surface of columns in the "Italian Garden" } \\
\hline 1 & $\begin{array}{l}\text { Gypsum-rich primary crust on the } \\
\text { column's capital. }\end{array}$ & $\begin{array}{l}\text { Main phase: calcite } \\
\text { A few: quartz, gypsum }\end{array}$ & \multicolumn{2}{|c|}{$\begin{array}{c}\text { Alternaria alternata } \\
\text { Alternaria tenuissima } \\
\text { Cladosporium cladosporioides } \\
\text { Epicoccum nigrum }\end{array}$} \\
\hline 2 & $\begin{array}{l}\text { Marble surface, with traces of } \\
\text { biodeterioration. No gypsum crust. } \\
\text { Sample collected near the patina } \\
\text { cover. }\end{array}$ & $\begin{array}{l}\text { Main phase: calcite } \\
\text { Trace amounts: quartz, } \\
\text { dolomite }\end{array}$ & \multicolumn{2}{|c|}{$\begin{array}{c}\text { Alternaria alternata } \\
\text { Alternaria tenuissima } \\
\text { Cladosporium cladosporioides } \\
\text { Epicoccum nigrum }\end{array}$} \\
\hline 3 & $\begin{array}{l}\text { Marble surface, with traces of } \\
\text { biodeterioration }\end{array}$ & $\begin{array}{l}\text { Main phase: calcite } \\
\text { Trace amounts: not } \\
\text { identified }\end{array}$ & $\begin{array}{c}\text { Alternaria alternata } \\
\text { Alternaria tenuissima } \\
\text { Cladosporium cladosporioides } \\
\text { Cladosporium sphaerospermum } \\
\text { Epicoccum nigrum } \\
\end{array}$ & $\begin{array}{c}\text { Mucor racemosus } \\
\text { Penicillium purpurogenum } \\
\text { Phaeosclera sp. } \\
\text { Ulocladium chartarum }\end{array}$ \\
\hline \multicolumn{5}{|c|}{ Samples of Chersonesian limestone, collected from the city walls } \\
\hline 4 & $\begin{array}{l}\text { Surface with traces of } \\
\text { biodeterioration. }\end{array}$ & $\begin{array}{l}\text { Main phase: calcite } \\
\text { Trace amounts: quartz }\end{array}$ & $\begin{array}{c}\text { Alternaria allternata } \\
\text { Aspergillus versicolor } \\
\text { Cladosporium cladosporioides } \\
\text { Cladosporium herbarum } \\
\text { Cladosporium sphaerospermum }\end{array}$ & $\begin{array}{l}\text { Epicoccum nigrum } \\
\text { Mucor racemosus } \\
\text { Penicillium citrinum } \\
\text { Phaeosclera sp. }\end{array}$ \\
\hline 5 & $\begin{array}{l}\text { Primary gypsum-rich crust on } \\
\text { limestone surface. }\end{array}$ & $\begin{array}{l}\text { Main phase: calcite } \\
\text { A few: quartz, gypsum }\end{array}$ & $\begin{array}{c}\text { Alternaria alternata } \\
\text { Alternaria tenuissima } \\
\text { Cladosporium cladosporioides }\end{array}$ & $\begin{array}{c}\text { Cladosporium } \\
\text { sphaerospermum } \\
\text { Epicoccum nigrum } \\
\text { Penicillium citrinum } \\
\end{array}$ \\
\hline 6 & $\begin{array}{l}\text { Primary gypsum-rich crust on } \\
\text { limestone surface, with traces } \\
\text { of salt efflorescence. }\end{array}$ & $\begin{array}{l}\text { Main phase: calcite } \\
\text { A few: quartz, gypsum } \\
\text { Trace amounts: halite }\end{array}$ & $\begin{array}{c}\text { Alternaria alternata } \\
\text { Chaetomium globosum } \\
\text { Cladosporium cladosporioides }\end{array}$ & $\begin{array}{c}\text { Cladosporium } \\
\text { sphaerospermum } \\
\text { Fusarium oxysporum } \\
\text { Penicillium citrinum } \\
\end{array}$ \\
\hline 7 & $\begin{array}{l}\text { Gypsum-rich secondary crust on } \\
\text { limestone surface. }\end{array}$ & $\begin{array}{l}\text { Main phase: calcite } \\
\text { A few: quartz, gypsum, } \\
\text { syngenite } \\
\text { Trace amounts: dolomite }\end{array}$ & \multicolumn{2}{|c|}{$\begin{array}{l}\text { Alternaria alternata } \\
\text { Aspergillus versicolor } \\
\text { Cladosporium cladosporioides } \\
\text { Penicillium decumbens } \\
\text { Penicillium sp. } \\
\end{array}$} \\
\hline
\end{tabular}

In the samples collected from the Proconesian marble surface, only the last two stages of patina formation were found (Fig. 6). Most of the gypsum crystals have a lamellar form, strongly flattened after the second pinacoid plane, (Figs. 5b, 6, and 7a). They often grow as rosettes covering the whole surface of the rock (Figs. $6 \mathrm{~b}$ and $7 \mathrm{a}$ ). Seldom, individual elongated prismatic crystals (Fig. 7b), poorlyshaped crystals with rounded faces (Fig. 5c) or cauliflowerlike irregular growth structures (Fig. 7c) occur as well.
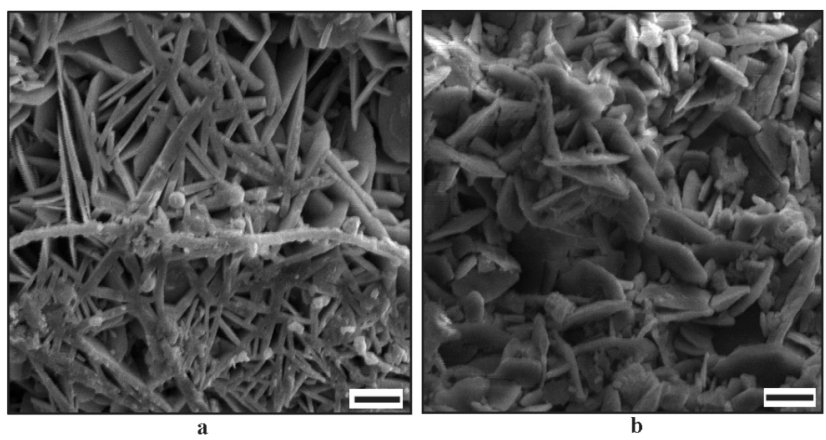

Fig. 6. SEM images of gypsum crystals and microorganisms of gypsum-rich patina on the Proconnesian marble:

$a$ - microorganisms occurring in between gypsum crystals (scale

bar $=12 \mu \mathrm{m}) ; b$-formation of a continuous layer of gypsum crystals (scale bar $=14 \mu \mathrm{m})$.

Comparing the gypsum crystals occurring in the Chersonesian limestones patina with those found by Timasheva et al. (2007) in Saint-Petersburg, despite a general resemblance due to the prevailence of flattened lamellar crystals, there are also clear differences. Thus, the gypsum crystals are packed closer and reach larger size (up to $240 \mu \mathrm{m}$ ) in the Chersonesian limestones patina (Fig. 7a), compared with St. Petersburg one.
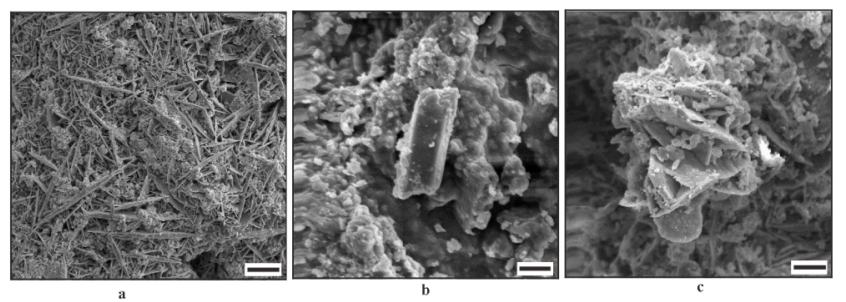

Fig. 7. SEM images of various forms of gypsum crystals:

$a$-flattened crystals forming rosettes (scale bar $=83 \mu \mathrm{m}$ );

$b$ - elongated prismatic crystals (scale bar $=14 \mu \mathrm{m})$;

$c$-cauliflower-like regular growth structures $($ scale bar $=24 \mu \mathrm{m})$.

The mineral composition of patinas on the Tauric Chersonesos limestones and marble monuments is close to that described for the Mediterranean monuments by GarciaVallès et al. (1998). So far no phenomenon of patina vanishing as noticed in Spain and Italy was ever recorded on the Chersonesos monuments. Most likely, the formation of gypsum-rich patina is due to the action of pollutants such as sulphuric acid. The warm and humid climate is favoring the developing of a rich association of micro-organisms.

\section{CONCLUSIONS}

The study of patina from the surface of ancient monuments of the Tauric Chersonesos site revealed a strong decay of both limestone and marble surfaces. The presence of biota, e.g., micromycetes, in all patina samples, shows the significant role of micro-organisms in the degradation 
processes of stone. The evolution of gypsum-rich patina formation both in Tauric Chersonesos and Saint Petersburg are similar and have the same main stages, despite the differences in climate. This may indicate that common aggressive factors, such as modern air pollution and the high humidity are the main causes for the stone decay.

Acknowledgments. The work was supported by the Russian Foundation of Basic Research (Projects 09-05-01062, 0906-90406). Authors thank Prof. O. V. Frank-Kamenetskaya and Dr. D. Yu. Vlasov for their valuable assistance during the study.

\section{R E F E R E N C E S}

Arx, von J.A. 1975, The genera of fungi sporulating in pure culture. J. Cramer Vaduz, $315 \mathrm{p}$.

De Hoog, G.S., Guarro, J. 1995, Atlas of clinical fungi. Centraalbureau voor Schimmelcultures, Baarn/ Universitat Rovira i Virgili, Reus, 720 p.

Garcia-Vallès, M., Vendrell-Saz, M., Molera, J. \& Blazquez, F. 1998, Interaction of rock and atmosphere: patinas on Mediterranean monuments. Environmental Geology, 36 (1-2): 137-149.
Gorbushina, A.A., Panina, L.K., Vlasov, D.Yu. \& Krumbein, W.E. 1996, Fungi injuring marble in Chersonesos. Micologia i Fitopatologia, 30 (4): 49-54 (in Russian).

Ellis, M.B. 1971, Dematiaceous Hyphomycetes. Commonwealth Mycological Institute Kew, 608 p.

Ellis, M.B. 1976, More Dematiaceous Hyphomycetes. Commonwealth Mycological Institute Kew, 507 p.

Lebedinskiy, V.I. 1982, Through the Crimea with a geological hammer. Nedra Moskwa, $159 \mathrm{p}$.

Timasheva, M.A., Frank-Kamenetskaya, O.V. \& Vlasov, D.Yu. 2007, The morphology and generation features of gypsum crystals on carbonate rocks surface in urban environment. Russian Mineralogical Society Notes, 5: 98-104 (in Russian).

Zelenskaya, M.S., Vlasov, D.Yu. 2006, Micromycetes on the monuments of National Preserve of Tauric Chersonesos (Crimea). Micologia $i$ Fitopatologia, 40 (5): 370-376 (in Russian).

Warren, J. 1999, Conservation of Brick. Elsevier, 294 p. 